\title{
P01.56. Does practicing Reiki alter the electromagnetic field of heart and hands of practitioners?
}

\author{
A Baldwin ${ }^{1 *}$ W Rand ${ }^{2}$, G Schwartz ${ }^{1}$ \\ From International Research Congress on Integrative Medicine and Health 2012 \\ Portland, Oregon, USA. 15-18 May 2012
}

\section{Purpose}

This study attempted to repeat experiments performed 20 years ago that detected exceptionally high strength electromagnetic fields $(100 \mathrm{nT})$ from the hands of several energy healers. The equipment utilized in this replication attempt was far more sensitive, and the magnetic shielding used to block confounding fields from electrical lines far more effective, than in the original studies.

\section{Methods}

Using a Magnes 2500 WH SQUID at Scripps Research Institute, San Diego, the electromagnetic field from the hands and heart of each of 3 Reiki masters was measured for 5 minutes when they were: (i) not practicing Reiki; (ii) sending Reiki to a distant person; and (iii) sending Reiki to a person in the room. Similar measurements were made on 4 Reiki-naïve volunteers before and after they received Reiki attunements enabling them to run Reiki energy through themselves.

\section{Results}

For all subjects, under all conditions, sensors closest to the heart and the hands produced spikes of $2 \mathrm{pT}$ corresponding to the heartbeat. Recordings from two Masters and one volunteer showed a low intensity sine wave oscillation of $0.25-0.3 \mathrm{~Hz}$ (intensity $0.1-0.5 \mathrm{pT}$ ) whether or not they were practicing Reiki. This oscillation probably reflected respiratory sinus arrhythmia, as judged by comparison with recent previous studies. These signals were not detected in the original studies. No segments of electromagnetic field intensity greater than $3 \mathrm{pT}$ were seen in any recording in the current study.

${ }^{1}$ University of Arizona, Tucson, USA

Full list of author information is available at the end of the article

\section{Conclusion}

These results suggest that practicing Reiki does not routinely produce high intensity electromagnetic fields from the palms. The previous findings could have been from a few exceptional healers. Alternatively, it is possible that energy healing is stimulated by attunement to an external environmental radiation, such as the Schumann resonance, which was blocked in the present study by the strong magnetic shielding in the room containing the SQUID.

\section{Author details}

${ }^{1}$ University of Arizona, Tucson, USA. ${ }^{2}$ Center for Reiki Research, Michigan, USA.

Published: 12 June 2012

doi:10.1186/1472-6882-12-S1-P56

Cite this article as: Baldwin et al:: P01.56. Does practicing Reiki alter the electromagnetic field of heart and hands of practitioners? BMC

Complementary and Alternative Medicine 2012 12(Suppl 1):P56.

Submit your next manuscript to BioMed Central and take full advantage of:

- Convenient online submission

- Thorough peer review

- No space constraints or color figure charges

- Immediate publication on acceptance

- Inclusion in PubMed, CAS, Scopus and Google Scholar

- Research which is freely available for redistribution
C Biomed Central

(c) 2012 Baldwin et al; licensee BioMed Central Ltd. This is an Open Access article distributed under the terms of the Creative Commons Attribution License (http://creativecommons.org/licenses/by/2.0), which permits unrestricted use, distribution, and reproduction in any medium, provided the original work is properly cited. 